\section{Quantitative Variation of the Common Acute Lymphoblastic Leukemia Antigen (gp100) on Leukemic Marrow Blasts}

\author{
A. Thomas Look, Susan L. Melvin, L. Keith Brown, \\ Michael E. Dockter, Paula K. Roberson, \\ and Sharon B. Murphy \\ Divisions of Hematology-Oncology, Pathology and Laboratory \\ Medicine, Biochemistry and Biostatistics, St. Jude Children's \\ Research Hospital, Memphis, Tennessee 38101
}

tient variation in quantitative expression of CALLA is consistent with recognized steps in B cell precursor differentiation and may be useful in distinguishing patients with a less favorable prognosis.

\section{Introduction}

The common acute lymphoblastic leukemia antigen (CALLA, also gp 100), ' which was discovered by Greaves et al. (1), is present on the blasts of most children with ALL and has been linked to a favorable prognosis (2-5). Detection of CALLA on leukemic cells was followed by recognition of a small population $(1-10 \%)$ of normal lymphoid precursors that also express the antigen, indicating that it is a marker of normal lymphoid cell differentiation (6-9). Biochemical studies have identified CALLA as a cell-surface glycoprotein of $100,000 \mathrm{D}(10-12)$, and monoclonal antibodies to the molecule have been developed $(13,14)$.

Korsmeyer et al. (15) recently found rearranged Ig genes and selective expression of surface antigens in 25 cases of socalled non-T, non-B ALL, which comprises the majority of cases of ALL in children. They interpreted this as evidence that such cases result from monoclonal expansion of $B$ cell precursors representing serial stages of Ig gene rearrangement and surface antigen expression. In their scheme, the earliest precursors bear only HLA-DR antigens, whereas cells with rearranged light chain genes possess both HLA-DR and CALLA. These findings prompted us to adopt the term "B cell precursor ALL" for cases that lack features of mature $T$ or $B$ cells and have either an HLA-DR $^{+}$, CALLA $^{-}$or HLA-DR ${ }^{+}$, CALLA $^{+}$phenotype.

We reasoned from studies with other differentiation antigens (16-20) that quantitation of CALLA on leukemic blasts might disclose substantial differences in its expression, which could be related to the predicted pattern of differentiation within the B precursor pathway (15). Additionally, since about one-third

1. Abbreviations used in this paper: ALL, acute lymphoblastic leukemia; CALLA, common acute lymphoblastic leukemia antigen; Clg, cytoplasmic Ig; E, sheep erythrocyte receptor; FCM, flow cytometry; Ig, immunoglobulin; WBC, white blood cell count. 
of children with a CALLA phenotype relapse within $2 \mathrm{yr}$ of diagnosis (2-5), quantitative levels of the antigen might distinguish patients with a greater risk of treatment failure. Using a recently developed flow cytometric (FCM) technique (21) that permits simultaneous measurement of surface antigen, DNA content and cell size, we studied the marrow blasts of 42 patients with B cell precursor ALL. The results demonstrate wide variability in mean CALLA expression from patient to patient, which is consistent with a hierarchy of B cell precursor differentiation, and may be important in predicting response to treatment.

\section{Methods}

Patients and treatment. Marrow blasts were collected before treatment from every child with ALL who was admitted from December 13, 1980 through December 31, 1981. Of 50 consecutive patients with $>10^{7}$ leukemic cells available for study after routine phenotyping, 42 had a diagnosis of B cell precursor ALL and therefore were eligible for FCM analysis. Six patients had T-cell ALL (5 positive for sheep erythrocyte

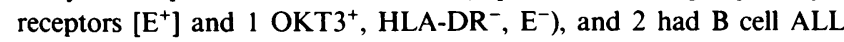
(surface $\mathrm{Ig}^{+}$). 27 additional patients with B cell precursor ALL, but too few blasts for FCM analysis, were admitted during the same period. Their treatment responses showed no appreciable deviation from those of the study group $(P=0.5)$. A summary of presenting clinical and laboratory features can be found in Table II.

All 42 patients with B cell precursor ALL were treated by St. Jude Total Therapy Study X protocol, which makes provision for two categories of risk assignment $(22,23)$. Briefly, a small percentage of children were judged to have "high-risk" ALL based on white blood cell (WBC) counts $>100 \times 10^{9} /$ liter, a mediastinal mass, central nervous system disease at diagnosis or E-rosette-forming blasts. They received $8 \mathrm{wk}$ of intensive early therapy, incorporating cytarabine plus teniposide (VM26), followed by 30 mo of 6-mercaptopurine and methotrexate with periodic pulses of cytarabine plus teniposide for the first $12 \mathrm{mo}$. The vast majority of patients $(93 \%)$ had none of the above features and therefore received therapy for "standard-risk" ALL: conventional remission induction and then either intermittent high-dose intravenous infusions of methotrexate or three alternating drug pairs for $18 \mathrm{mo}$. Both regimens concluded with 12 mo of 6-mercaptopurine and methotrexate. Follow-up observations have indicated no important differences in outcome for standard-risk patients treated in Study X.

These investigations were part of a larger cell profile study approved by the institution's clinical trials committee.

Lymphoblastic cell line. The NALM-1 human lymphoblastic cell line (24) (provided by Dr. J. Minowada, Department of Pathology, Stritch School of Medicine, Loyola University) was used as a CALLApositive control and for studies of cell diameter in relation to forwardangle light scatter.

CALLA and DNA staining. Bone marrow lymphoblasts were obtained from patients at diagnosis after Ficoll-Hypaque separation of heparinized aspirates. Aliquots of $5 \times 10^{6}$ cells each were incubated for $30 \mathrm{~min}$ on ice with $100 \mu \mathrm{l}$ of a 1:200 dilution of either the CALLA-specific J-5 monoclonal antibody (13) (provided by Dr. Jerome Ritz and Dr. Stuart Schlossman, Division of Tumor Immunology, Dana-Farber Cancer Institute, and Department of Medicine, Harvard Medical School) or the UPC10 IgG2a isotype-matched myeloma control protein (Litton Bionetics, Kensington, MD). The cells were washed three times at $4^{\circ} \mathrm{C}$ and incubated for $30 \mathrm{~min}$ on ice with $100 \mu \mathrm{l}$ of a 1:20 dilution of fluorescein- conjugated goat antimouse Ig (Tago, Inc., Burlingame, CA). Both the $\mathrm{J}-5$ and the goat antimouse Ig reagents were used in excess, based on tests of serial dilutions with the NALM-1 cell line. Stained cells were washed three times at $4^{\circ} \mathrm{C}$, resuspended in $1 \mathrm{ml}$ of cold phosphatebuffered saline (PBS), and fixed by dropwise addition of $3 \mathrm{ml}$ of cold $95 \%$ ethanol during vortexing. Fixed cells were stored for up to $5 \mathrm{~d}$ at $4^{\circ} \mathrm{C}$ before FCM analysis. Studies with the NALM-1 cell line disclosed no change of fluorescein fluorescence of the CALLA-stained cells over this time period.

Immediately before FCM analysis, cells were stained for DNA with propidium iodide using a modification of the method of Crissman and Steinkamp (25). Cells in ethanol were pelleted and resuspended in $5 \mathrm{ml}$ of cold PBS. Ribonuclease $(50 \mu \mathrm{g} / \mathrm{ml}$; bovine pancreas, CalbiochemBehring, Corp., La Jolla, CA) was added to the cell suspension, which was then incubated for $30 \mathrm{~min}$ at room temperature. Cells were pelleted and resuspended in $1 \mathrm{ml}$ of PBS containing $0.05 \mathrm{mg} / \mathrm{ml}$ propidium iodide (Calbiochem-Behring Corp.) at $4^{\circ} \mathrm{C}$. Just before FCM analysis, the stained cell suspensions were filtered through $37-\mu \mathrm{m}$ monofilament mesh (Small Parts, Inc., Miami, FL) to remove any large debris.

Flow cytometry. The stained cell suspensions were analyzed at a flow rate of $\sim 200$ cells/s with an EPICS-V flow cytometer (Coulter Electronics, Inc., Hialeah, FL) after excitation by a Spectra-Physics $164-$ 05 argon ion laser, adjusted to deliver $1 \mathrm{~W}$ at $488 \mathrm{~nm}$. Interference $(510$ $\mathrm{nm})$ and long-wavelength $(515 \mathrm{~nm})$ pass filters were used to prevent detection of scattered laser light $\left(90^{\circ}\right)$ by the photomultipliers. The red (propidium iodide) and green (fluorescein) fluorescence components of the emitted light were separated with a dichroic $(560 \mathrm{~nm})$ filter for subsequent quantitation. Before detection with separate photomultipliers, each component of the emitted light was filtered further by use of a 560 -nm short wavelength pass filter for green fluorescence and a 610$\mathrm{nm}$ long wavelength pass filter for red fluorescence. A differential amplifier was used to correct for overlap of the red fluorescence emission spectrum of propidium iodide into the green fluorescence emission spectrum of fluorescein (26). In practice, the high voltage of the green photomultiplier was set at 900 , and the differential amplifier was adjusted so that the signal from an aliquot of cells stained only with propidium iodide was orthogonal to the red fluorescence axis of the two-parameter red and green fluorescence display on the MDADS minicomputer (Coulter Electronics, Inc.). The gain of the green fluorescence could then be adjusted to center the J-5 green fluorescence on a linear scale for each patient, since the effect of the differential amplifier is independent of the gain setting. The cells stained with the UPC 10 monoclone were then analyzed at the same gain setting as the cells stained for the J-5 monoclone. Forward-angle light scatter $\left(1-19^{\circ}\right)$ was measured with a photo-detector array.

To correlate relationships among the different cellular features analyzed, each FCM analysis of cells stained with CALLA or control protein was stored directly on a floppy disk in the MDADS minicomputer. These "list-mode" discs contained the correlated measurements of red fluorescence, green fluorescence, and forward-angle light scatter for each of $\sim 8 \times 10^{4}$ cells. The relationships between relative DNA content (red fluorescence) and either green fluorescence or forward-angle light scatter were visualized by constructing two-parameter $(128 \times 128$ channel), three-dimensional histograms from the list-mode data with the MDADS minicomputer. Data retrieved by list-mode analysis were transferred to a Data General MV8000 computer (Data General Corp., Westboro, MA) for further analysis and for one- or two-parameter graphic display on a Tektronix 4662 plotter.

To quantify the green fluorescence and forward-angle light scatter of cell subpopulations defined by relative DNA content, we constructed 
gate windows on the red fluorescence parameter and analyzed the listmode discs with the MDADS minicomputer. For each CALLA ${ }^{+}$case, both green fluorescence and forward-angle light scatter were determined as 256-channel single-parameter histograms for the following electronically gated subpopulations of cells defined by DNA content: $(a)$ all cells regardless of cell cycle position, $(b) \mathrm{G}_{0} / \mathrm{G}_{1}$ phase diploid cells, (c) $\mathrm{G}_{0} / \mathrm{G}_{1}$ phase aneuploid leukemia cells, if distinguishable from diploid, and $(d) S$ phase cells. To minimize overlap between $G_{0} / G_{1}$ phase and early $S$ phase regions, we analyzed the $G_{0} / G_{1}$ phase cells to the left of the $G_{0} / G_{1}$ phase mode; $S$ phase cells were gated to exclude the regions of overlap with the right side of the $G_{0} / G_{1}$ phase mode and the left side of the $G_{2}+M$ phase mode. The cells with $G_{2}+M$ phase DNA content could not be analyzed owing to contamination with up to $9 \% G_{0} / G_{1}$ phase cell doublets. For CALLA ${ }^{+}$patients with the highest percentages of cells in $\mathrm{S}$ phase, we also determined green fluorescence and lightscatter histograms for three equal subdivisions of $S$ phase: early, mid, and late. Patterns of green fluorescence and light scatter during $\mathrm{S}$ phase were identical on two-parameter histograms for these 10 patients and the remaining CALLA ${ }^{+}$cases.

The percentage of cells bearing CALLA antigen was determined by scaling the mode of the UPC10 control antibody fluorescence histogram to the value of the corresponding $\mathrm{J}-5$ fluorescence histogram in the same channel, and subtracting the UPC10 results from the J-5 data. The cell number in this subtracted histogram, representing the cells with J-5 fluorescence greater than control, was then divided by the total cell number in the J-5 fluorescence histogram and multiplied by 100 to determine the percentage of CALLA ${ }^{+}$cells. The mean CALLA-specific fluorescence was then calculated from the subtracted histogram. All samples contained $>75 \%$ lymphoblasts by differential count of Wrightstained cells, and cases were considered CALLA ${ }^{+}$if $>25 \%$ of cells expressed the antigen at levels exceeding the control.

To construct standard relative scales for red and green fluorescence as well as light scatter, we analyzed fluorospheres (1/8 Brite, $10-\mu \mathrm{m}$ diameter, Coulter Electronics, Inc.) before each cell sample and assigned values of 100 units to the fluorosphere channel number on each scale. The red and green fluorescence scales were also corrected on the basis of the forward-angle light scatter of the fluorospheres, since light scatter was directly proportional to laser power. Red fluorescence of the diploid $G_{0} / G_{1}$ cells provided an internal standard for the calculation of relative fluorescence from sample to sample; the mean $( \pm \mathrm{SD})$ value for the 35 $\mathrm{CALLA}^{+}$patients was $679 \pm 49$ relative units. The reproducibility of FCM measurement of CALLA fluorescence and forward-angle light scatter, tested with the NALM- 1 cell line $(80,000$ cells per study), is illustrated in Table $\mathrm{I}$. The results represent testing intervals that coincide with those in clinical investigations.

FCM analysis of DNA content of stained nuclei. An aliquot of marrow cells from each patient was stained directly with hypotonic propidium iodide citrate solution (27), and cellular DNA content distributions obtained with this technique were compared with those derived from cell populations stained with both fluorescein and propidium iodide after fixation. DNA content histograms of marrow blasts were analyzed for DNA index, coefficient of variation of the $G_{0} / G_{1}$ phase leukemic cells, and the percentage of $S$ phase cells, as previously described (28).

Leukemia cell phenotype. Cells from these patients were also examined for the presence of HLA-DR molecules by use of the I 2 monoclonal antibody (29) (provided by Dr. Lee Nadler and Dr. Stuart Schlossman, Division of Tumor Immunology, Dana-Farber Cancer Institute, and Department of Medicine, Harvard Medical School). The assay for cytoplasmic $\mathrm{Ig}(\mathrm{Clg})$ was performed by a published method (30).

Centrifugal elutriation. The NALM-1 cells were separated according
Table I. Reproducibility of Quantitation of CALLA Fluorescence and Light Scatter by Cell Cycle Phase for NALM-1 Cells

\begin{tabular}{llllll}
\hline & \multicolumn{2}{l}{ CALLA fluorescence* } & & \multicolumn{2}{l}{ Forward-angle light scatter* } \\
\cline { 2 - 3 } & $\mathrm{G}_{0} / \mathrm{G}_{1}$ & $\mathrm{~S}$ & & $\mathrm{G}_{0} / \mathrm{G}_{1}$ & $\mathrm{~S}$ \\
\hline $\begin{array}{c}\text { Triplicate } \\
\text { study } \\
\begin{array}{c}\text { Serial } \\
\text { study }\end{array}\end{array}$ & $3.53 \pm 0.43$ & $4.09 \pm 0.52$ & & $8.08 \pm 0.05$ & $10.4 \pm 0.05$ \\
\hline
\end{tabular}

* Mean \pm SD.

¥ Three separate studies performed at the beginning, middle, and end of the clinical determinations.

to size by centrifugal elutriation at $4^{\circ} \mathrm{C}$ in a Beckman $\mathrm{J}-21 \mathrm{C}$ centrifuge (Beckman Instruments, Inc., Palo Alto, CA) equipped with a JE-6 elutriator rotor exactly as described (31). Seven fractions, $100 \mathrm{ml}$ each, were collected at flow rates of $5.0-9.0 \mathrm{ml} / \mathrm{min}$. The first fraction was discarded because it contained mainly debris and dead cells. Cells in each fraction were collected by centrifugation and resuspended in cold PBS.

The mean cell diameter of each fraction was determined with an Elzone 80XY particle counter (Particle Data, Inc., Elmhurst, IL). Mean forward-angle light scatter was determined by FCM for viable cells and ethanol-fixed cells that had been resuspended in PBS.

Statistical analysis. All statistical procedures except those related to disease-free survival were done with the Minitab computing system (32); specific tests are identified in the Results section. Times to failure, as of July 1, 1983, were plotted by the Kaplan-Meier method (33), and the resulting curves compared by the log-rank test (34). Time to failure was defined as the interval between achievement of remission and relapse or death due to any cause. Patients who failed to enter remission were assigned a failure time of zero. The influence of potential prognostic factors on outcome was estimated with the proportional hazards model of Cox (35). Each factor was considered as a single regression variable, and those achieving significance were analyzed in combination.

\section{Results}

Phenotypic markers and DNA content. CALLA was detectable with the J-5 monoclonal antibody only on marrow blasts from 35 of the 42 patients with B cell precursor ALL, nine of whom had cells positive for $\mathrm{CIg}$, a phenotypic marker of pre-B cell ALL (30). In two cases, CALLA ${ }^{+}$blasts failed to react with the I2 antibody; both were $\mathrm{CIg}^{+}$, and in one, the cells reacted with a heterologous anti-HLA-DR antiserum. The distribution of clinical features and cell markers among CALLA ${ }^{+}$patients (Table II) was similar to findings in other series (2-5) and to those for our seven HLA-DR ${ }^{+}$, CALLA ${ }^{-}$patients.

DNA content abnormalities, determined by FCM analysis, were apparent in marrow blasts from eight CALLA ${ }^{+}$patients: seven had single hyperdiploid leukemic stem lines (median DNA index of 1.20, range 1.14-2.0) and one had tetraploid and hypotetraploid lines in addition to a diploid line. Increased cellular DNA content was also found in cells of two patients with CALLA $^{-}$B precursor ALL. 
Table II. Distribution of Clinical Features and Cell Phenotypes Among 42 Patients with B Cell Precursor ALL

\begin{tabular}{|c|c|c|}
\hline Characteristic & $\begin{array}{l}\text { CALLA }^{+} \\
(n=35)\end{array}$ & $\begin{array}{l}\text { CALLA }^{-} \\
(n=7)\end{array}$ \\
\hline \multicolumn{3}{|l|}{ Sex } \\
\hline Boys & $23^{*}$ & 4 \\
\hline Girls & 12 & 3 \\
\hline \multicolumn{3}{|l|}{ Race } \\
\hline White & 33 & 6 \\
\hline Black & 2 & 1 \\
\hline \multicolumn{3}{|l|}{ Age $(y r)$} \\
\hline$<2$ & 2 & 1 \\
\hline $2-10$ & 25 & 4 \\
\hline$>10$ & 8 & 2 \\
\hline \multicolumn{3}{|l|}{$\mathrm{WBC}\left(\times 10^{9} /\right.$ liter $)$} \\
\hline$<50$ & 29 & 6 \\
\hline $50-100$ & 5 & 1 \\
\hline$>100$ & 1 & 0 \\
\hline \multicolumn{3}{|l|}{ Spleen size $(\mathrm{cm})$} \\
\hline$\leq 4$ & 29 & 5 \\
\hline$>4$ & 6 & 2 \\
\hline \multicolumn{3}{|l|}{ Risk of Failure } \\
\hline Highł & 3 & 0 \\
\hline Standard§ & 32 & 7 \\
\hline \multicolumn{3}{|c|}{ Composite Phenotype" } \\
\hline HLA-DR ${ }^{+}, \mathrm{Clg}^{+}$ & 7 & 2 \\
\hline HLA-DR ${ }^{-}, \mathrm{Clg}^{+}$ & 2 & 0 \\
\hline HLA-DR ${ }^{+}, \mathrm{Clg}^{-}$ & 24 & 5 \\
\hline
\end{tabular}

* Number of patients.

$\ddagger$ WBC count $>100 \times 10^{9} /$ liter, mediastinal mass, central-nervoussystem leukemia, or blast cells that bind sheep erythrocytes at $37^{\circ} \mathrm{C}$. $\S$ Absence of any high-risk features.

"Two CALLA ${ }^{+}$, HLA-DR" patients were not tested for Clg.

The percentage of $\mathrm{S}$ phase cells among $\mathrm{CALLA}^{+}$patients was typically low, whether determined with freshly stained nuclei (median $8.4 \%$, range $2.4-15.3 \%$ ) or ethanol-fixed cells (median $9.6 \%$, range $3.7-16.5 \%$ ). Although fixed $G_{0} / G_{1}$ phase cells had a higher median CV than did freshly stained nuclei (3.2 vs. $2.4 \%$ ), the prevalence of aneuploidy was the same with either method of cell preparation.

Simultaneous measurement of CALLA expression, DNA content, and light scatter. Fig. 1 shows typical results of an FCM analysis of cells from a hyperdiploid CALLA ${ }^{+}$patient. The antigen was detected over a broad range of fluorescence intensity $(A)$; also evident, in the region of lowest intensity, was a subpopulation of CALLA ${ }^{-}$cells that were indistinguishable from cells stained with the isotype control monoclone. The leukemic $\mathrm{G}_{0} / \mathrm{G}_{1}$ phase cells in this sample $(B)$ had sharply increased DNA content by comparison with the residual population of diploid cells. Forward-angle light scatter, a measure primarily dependent

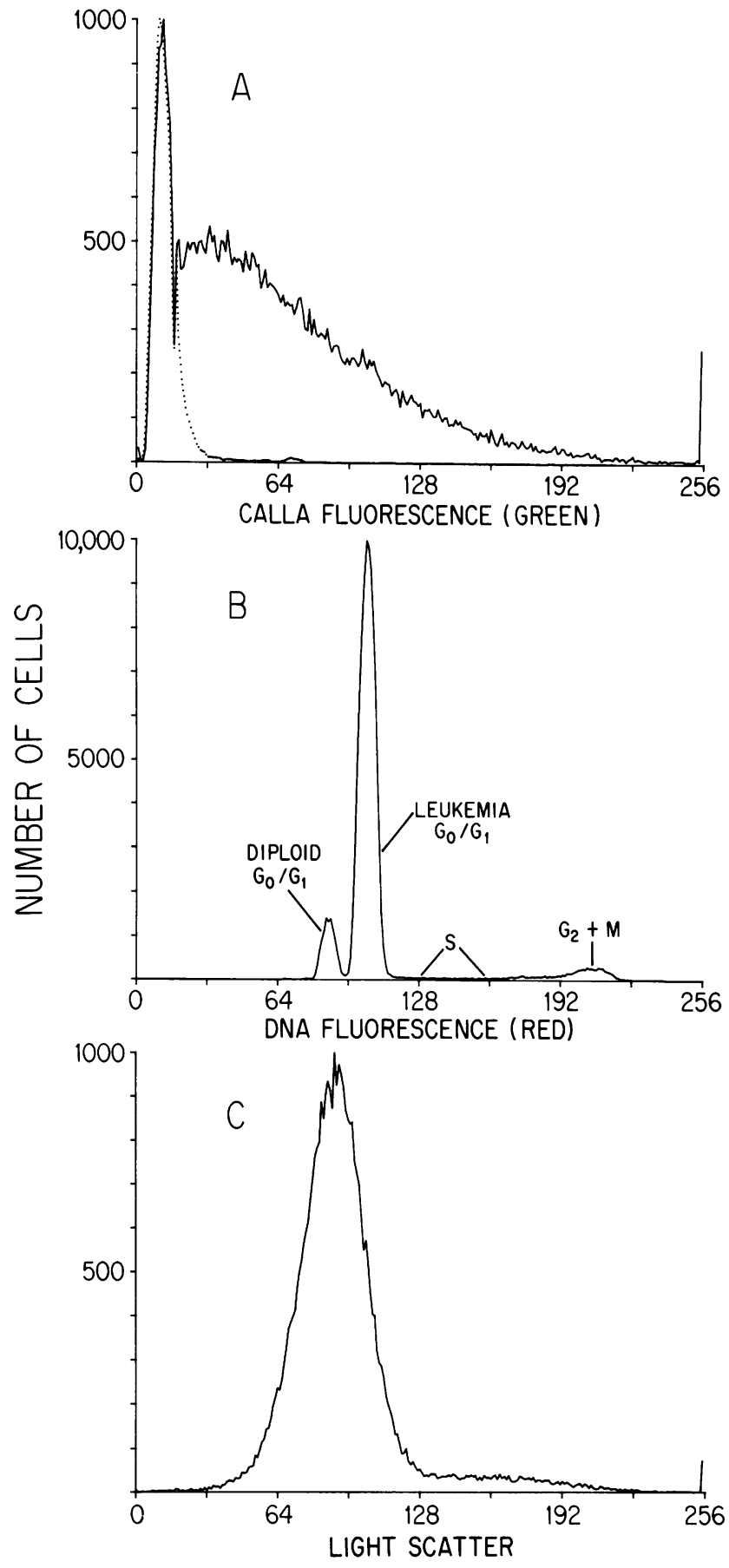

Figure 1. Histograms of CALLA expression, DNA content, and light scatter of marrow blasts from a hyperdiploid CALLA ${ }^{+}$patient at diagnosis. $A$ compares the fluorescence intensity of fluorescein-labeled antibody bound to CALLA as recognized by either the J-5 monoclone (solid line) or an isotype control monoclone (dotted line). Analysis of DNA content $(B)$ shows a hyperdiploid malignant stem line with $G_{0} / G_{1}$ DNA content 1.2 times the diploid value. A small population of diploid $G_{0} / G_{1}$ cells is also present. The light scatter histogram $(C)$ shows the majority of cells in a unimodal population, with a minor population of cells having higher values. 
on cell size (36), indicated a narrow range of values in the dominant peak of cells, with higher values in the residual population $(C)$.

A distinction between CALLA expression by diploid and hyperdiploid cells can be made from the correlated measurements shown in Fig. 2. By FCM analysis, the diploid $G_{0} / G_{1}$ phase cells accounted for $7 \%$ of the total cell population, in agreement with the $5 \%$ of nonlymphoblastic cells observed in a Wright-stained cytocentrifuge preparation. These diploid cells were clearly $\mathrm{CALLA}^{-}$as shown in the foreground of Fig. $2 \mathrm{~A}$, and were evident in both the $S$ and $\mathrm{G}_{2}+M$ phases of the cell cycle as well as $G_{0} / G_{1}$ (Fig. $2 B$ ). By contrast, the CALLA ${ }^{+}$ region of the figure consisted of hyperdiploid cells only. The $11 \%$ of cells with hyperdiploid $G_{0} / G_{1}$ DNA content that were considered $\mathrm{CALLA}^{-}$consisted partly of $\mathrm{CALLA}^{-}$diploid cells in $S$ phase and partly of a shoulder of the CALLA ${ }^{+}$distribution

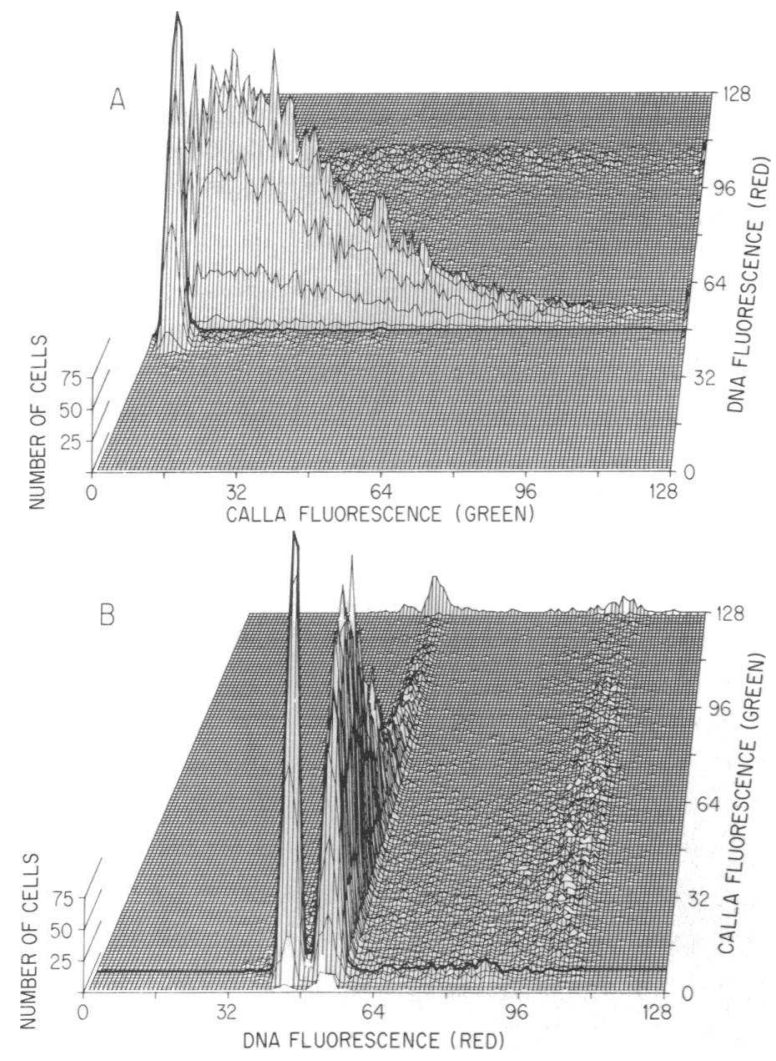

Figure 2. Correlated analysis of DNA content and CALLA of marrow from the same patient studied in Fig. 1. In $A$, the bold line (channel 48 on the $Y$ axis) separates the diploid $G_{0} / G_{1}$ cells (foreground) from the hyperdiploid $G_{0} / G_{1}$ cells. The former are clearly CALLA negative, whereas the latter show a broad range of CALLAspecific fluorescence. The CALLA-negative region, shown in the foreground of $B$ and outlined by a bold line (channel 7 on the $Y$ axis), includes the diploid $G_{0} / G_{1}, S$, and $G_{2}+M$ phase cells. The hyperdiploid leukemic cells in $G_{0} / G_{1}, S$, and $G_{2}+M$ phase are CALLA positive, with a broad range of CALLA-specific fluorescence per cell within each region of the cell cycle. that extended into the zone of green fluorescence and was indistinguishable from cells of the control monoclone. Similar results were obtained for each of the remaining six patients with single hyperdiploid stem lines. We infer from these results that essentially all hyperdiploid leukemic cells were $\mathrm{CALLA}^{+}$, and more importantly, that CALLA expression was not restricted to any single phase of the cell cycle.

Tetraploid leukemic stem lines pose a special problem in surface antigen analysis because they are usually found in combination with diploid lines (28). Tetraploid lines were found in two of the CALLA ${ }^{+}$cases in this study. In the first, the tetraploid cells were CALLA ${ }^{+}$and the diploid cells CALLA ${ }^{-}$(Fig. 3), as was noted for the other six hyperdiploid cases. In the second case, however, the diploid $\mathrm{G}_{0} / \mathrm{G}_{1}$ cells contained both CALLA ${ }^{+}$ and CALLA ${ }^{-}$cells (Fig. 4). Tetraploid and hypotetraploid stem lines were also evident in this case, and both expressed the CALLA marker as judged from correlated measurements of cellular DNA content and CALLA expression.

Among the $27 \mathrm{CALLA}^{+}$patients with single diploid leukemic stem lines, it was not possible to distinguish CALLA $^{-}$residual diploid cells from $\mathrm{CALLA}^{+}$cells by FCM analysis of DNA content. However, cells lacking the antigen formed a sharp peak that was distinct from the profile for CALLA ${ }^{+}$cells, as shown by the diploid portion of Fig. $4 C$.

Influence of cell size on CALLA expression. Forward-angle light scatter increased sharply as cells moved from $G_{0} / G_{1}$ through $S$ phase (Fig. 5), emphasizing the need to consider cell size in quantitation of CALLA on cycling lymphoblasts. To relate light scatter to blast surface area and cell cycle phase, we separated NALM-1 lymphoblasts into six fractions by centrifugal elutriation. The fractions contained successively larger cells, as determined from Coulter diameter, with corresponding enrichment for $S$ phase and $G_{2}+M$ phase cells (Fig. 6). The mean light scatter of each fraction was linearly related to cell surface area, as calculated from mean cell diameter assuming a spherical cell shape (Fig. 7). Using this relationship as a basis for calculating the surface area of patients' blasts, we were able to show that, despite a progressive increase in CALLA-associated fluorescence per cell from $G_{0} / G_{1}$ through $S$ phase (Fig. $8 A$ ), CALLA density remained relatively constant (Fig. $8 \mathrm{~B}$ ).

Interpatient variation of CALLA expression. Mean relative CALLA expression by leukemic blasts varied widely among the 35 patients, from very high to marginally detectable (Fig. 9). The antigen was more abundant on $\mathrm{S}$ phase cells, but changes in its amount due to cell cycle phase accounted for only a small fraction of the interpatient variability. Similarly, interpatient differences in light scatter and percentage of cells in $S$ phase were poorly correlated with quantitative level of CALLA ( $r$ $=0.362$ and $r=0.069$, respectively), as were differences in DNA content (median CALLA expression in hyperdiploid cases $=7.24$ relative units vs. 6.91 in diploid cases, $P=1.00$ by the Mann-Whitney test). The presence or absence of CIg in lymphoblasts had no demonstrable relation to amount of CALLA (median of 9.5 relative units for $\mathrm{CIg}^{+}$patients vs. 7.0 for $\mathrm{CIg}^{-}$, $P=0.41$ by the Mann-Whitney test). 


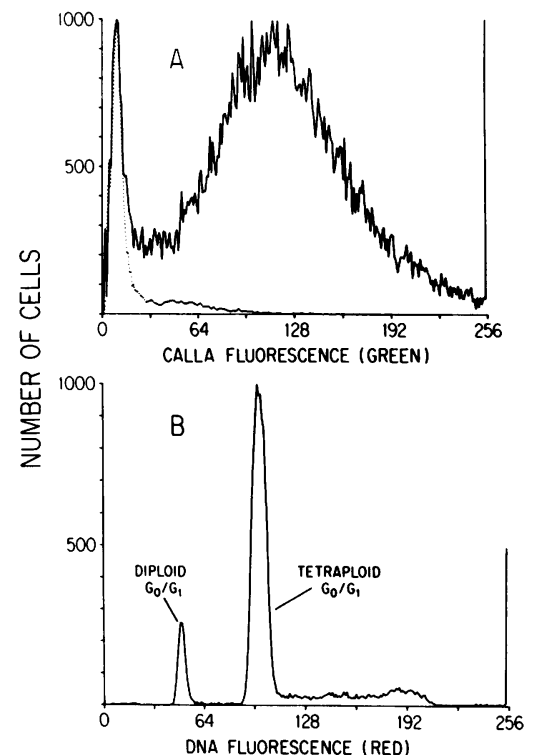

Figure 3. Cellular CALLA expression and DNA content of bone marrow cells from a patient with a single tetraploid leukemic stem line. From single-parameter histograms of CALLA expression $(A)$ and DNA content $(B)$, it is impossible to determine whether the diploid stem line expresses the CALLA marker. The three-dimensional dia-

CALLA expression and response to therapy. The prognostic importance of relative CALLA amount was assessed by comparing time-to-failure curves for three categories of patients:

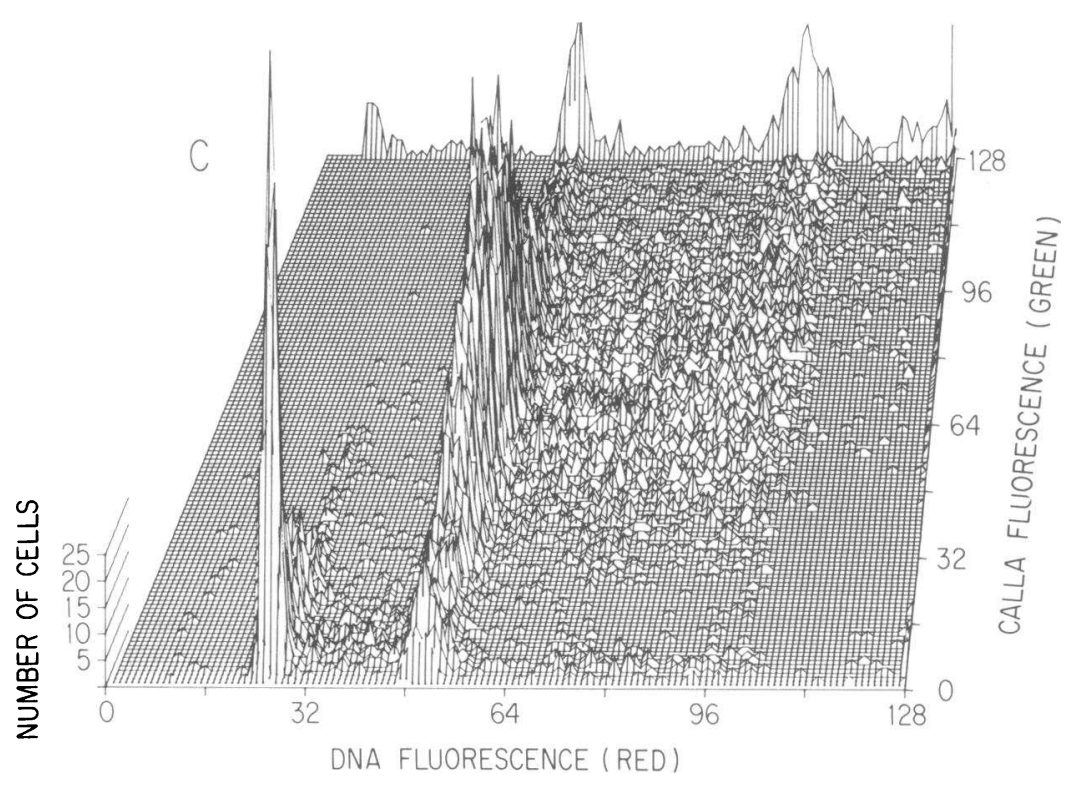

gram $(C)$ shows that the diploid $\mathrm{G}_{0} / \mathrm{G}_{1}$ cells are CALLA negative. This result agrees with the differential count for Wright-stained preparations: $93 \%$ lymphoblasts compared with $90 \%$ of cells with tetraploid DNA content $(B)$.

those with CALLA-associated fluorescence equal to or greater than the median value, those with lower values, and those lacking detectable CALLA. Separate tests were done for the same de-

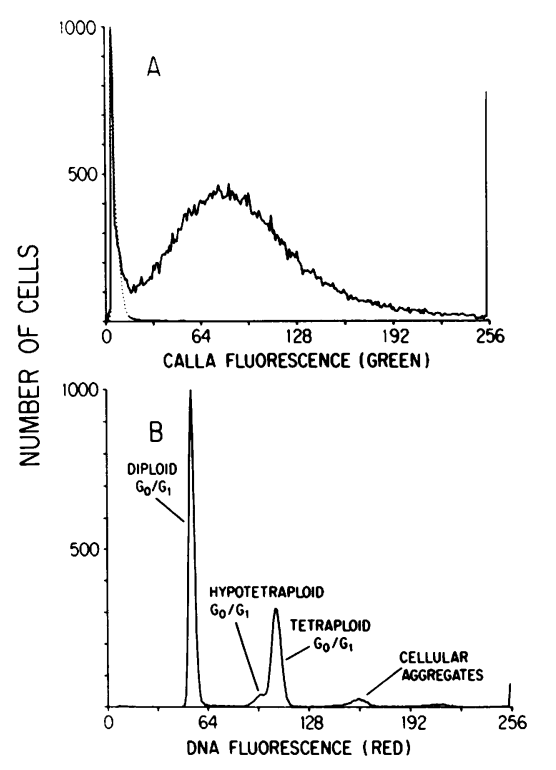

Figure 4. Cellular CALLA expression and DNA content of bone marrow cells from a patient with three leukemic stem lines. Since 92\% of cells were CALLA positive $(A)$, some diploid cells must express the CALLA marker, but it cannot be determined from the DNA content distribution $(B)$ whether the hypotetraploid and tetraploid stem lines also express this marker. From the correlated dia-

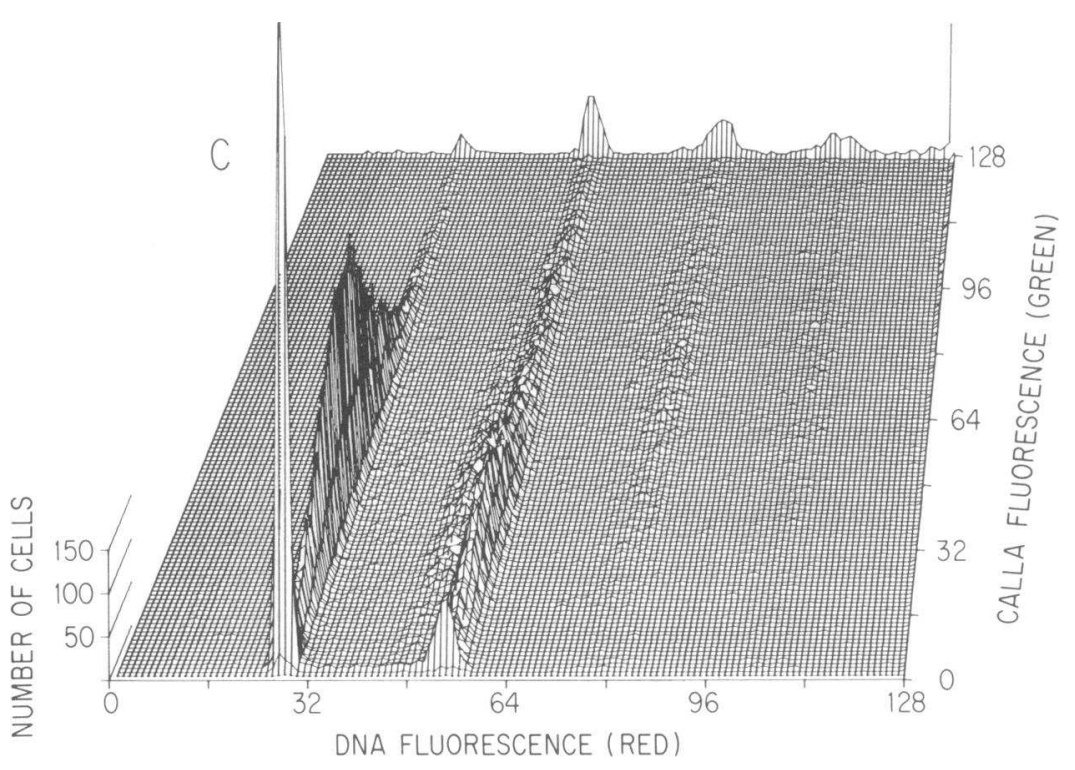

gram $(C)$, the diploid $\mathrm{G}_{0} / \mathrm{G}_{1}$ population appears to contain both CALLA-positive $(89 \%)$ and CALLA-negative $(11 \%)$ cells. The hypotetraploid and hypertetraploid $G_{0} / G_{1}$ cells are almost entirely CALLA positive, indicating that all three leukemic stem lines express the marker. This sample was $\mathbf{8 5 \%}$ lymphoblasts by differential count of Wright-stained preparations. 

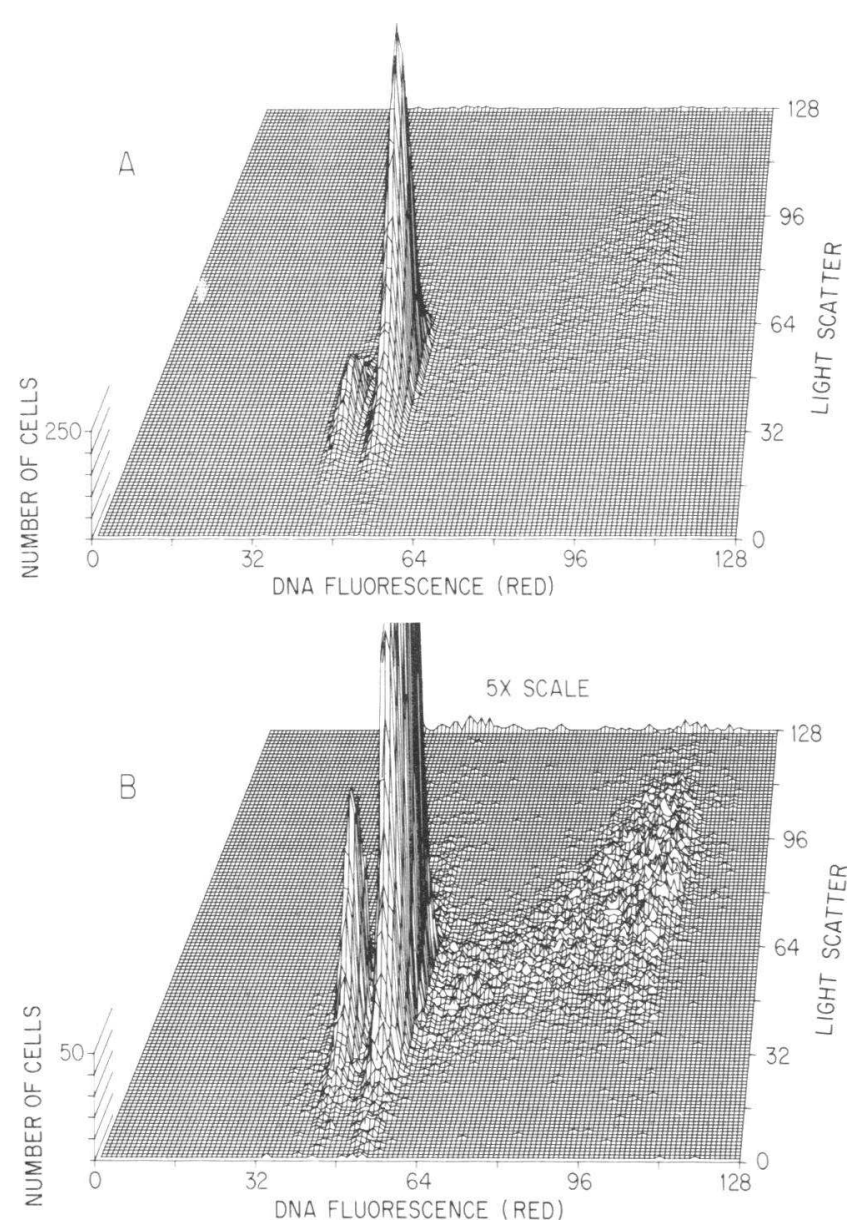

Figure 5. Correlated analysis of cellular DNA content and light scatter for bone marrow lymphoblasts from the same patient studied in Figs. 1 and 2 . The hyperdiploid $G_{0} / G_{1}$ leukemia cells have increased mean light scatter compared with the diploid $\mathrm{G}_{0} / \mathrm{G}_{1}$ cells $(A)$. The mean light scatter per cell increases as leukemic cells progress from $\mathrm{G}_{0} / \mathrm{G}_{1}$ through $\mathrm{S}$ phase, with a tight distribution of light scatter at each position in the cell cycle $(B)$.

terminations on $S$ phase, $G_{0} / G_{1}$ phase, and combined cell populations. With a median time to failure or last follow-up of 20 mo (range 0-28 mo), the greatest difference in remission duration $(P=0.058)$ was found between groups identified by $\mathrm{S}$ phase CALLA above or below 9.4 relative units (Fig. 10). After 12 mo of therapy, the time-to-failure curve for patients with lower amounts of S phase CALLA was nearly identical to that for the CALLA $^{-}$group.

To refine our analysis, we sought cutoff points that might yield greater statistical significance in a comparison of times to failure. The findings were 9.6 relative units for $S$ phase CALLA $(P=0.03)$ and 9.4 for $\mathrm{G}_{0} / \mathrm{G}_{1}$ phase CALLA $(P=0.09)$. Thus, even with values giving maximal separation, $S$ phase CALLA provided the most reliable prediction of treatment outcome.

Certain clinical and laboratory features have been closely linked to disease-free survival in ALL (2-5); hence, we analyzed potential prognostic factors using the Cox proportional hazards model (Table III). Aside from quantitative level of $S$ phase CALLA $(P=0.048)$, only log WBC achieved significance $(P$ $=0.012$ ). The model predicted a threefold greater relative risk of relapse for patients with lower S phase CALLA, even after adjustment for WBC. A combination of lower S phase CALLA and higher WBC was associated with a 14-fold greater risk of failure than was the opposite combination. The gain in prognostic information obtained by combining S phase CALLA with WBC can be readily appreciated from the Kaplan-Meier analysis depicted in Fig. 11.

\section{Discussion}

ALL appears to be the result of clonal expansion of transformed lymphoid progenitor cells unable to complete normal differentiation programs. By studying the expression of certain differentiation-linked molecules on leukemic cells, it has been possible to classify most cases of ALL into broad subcategories that correspond to stages of normal lymphoid cell development (2). Within the B cell precursor series, for instance, patterns of phenotypic markers uniformly include HLA-DR and over half include CALLA $(2-5,14)$. In previous studies of the immunologically defined subclasses of ALL (2-5), phenotypic markers have been identified on the basis of monoclonal antibody binding or reactivity with specific heteroantisera relative to an appropriate background control. The results have been expressed as positive or negative, depending on the percentage of positive cells taken as an acceptable cutoff point, with no attempt made to estimate amount of binding.

In this report, we demonstrate wide variation in quantitative level of CALLA, extending to the lower limit of detection by our FCM technique, among 35 of 42 patients with B cell precursor ALL. Quite possibly, the seven apparently CALLA ${ }^{-}$patients represent an extension of this quantitative variation that was not apparent with our analytical method. Their clinical and laboratory features at diagnosis were similar to those of the $\mathrm{CALLA}^{+}$group, and their treatment responses have been virtually identical to those of patients with lower CALLA amounts. Fixation of cells and simultaneous staining with propidium iodide reduces the sensitivity of CALLA detection techniques, by comparison with findings for unfixed cells. Whether use of unfixed cells with more sensitive FCM methods would improve detection of very low levels of CALLA on cells of the B precursor series clearly deserves investigation.

The wide interpatient variation in CALLA expression could not be attributed to factors with potential biological influence (e.g., cell size, stem-line DNA content, or percentage of cells in $S$ phase). Rather, it appears to reflect the coordinate sequence of B cell precursor differentiation proposed by Korsmeyer et al. (15). In their model, all cells with recombined light and heavy chain Ig genes express both CALLA and HLA-DR, whereas cells with only rearranged heavy chain genes express HLA-DR with or without detectable CALLA. In view of the wide quantitative variation of CALLA expression revealed by FCM analysis, we propose that cases with only heavy chain gene rear- 

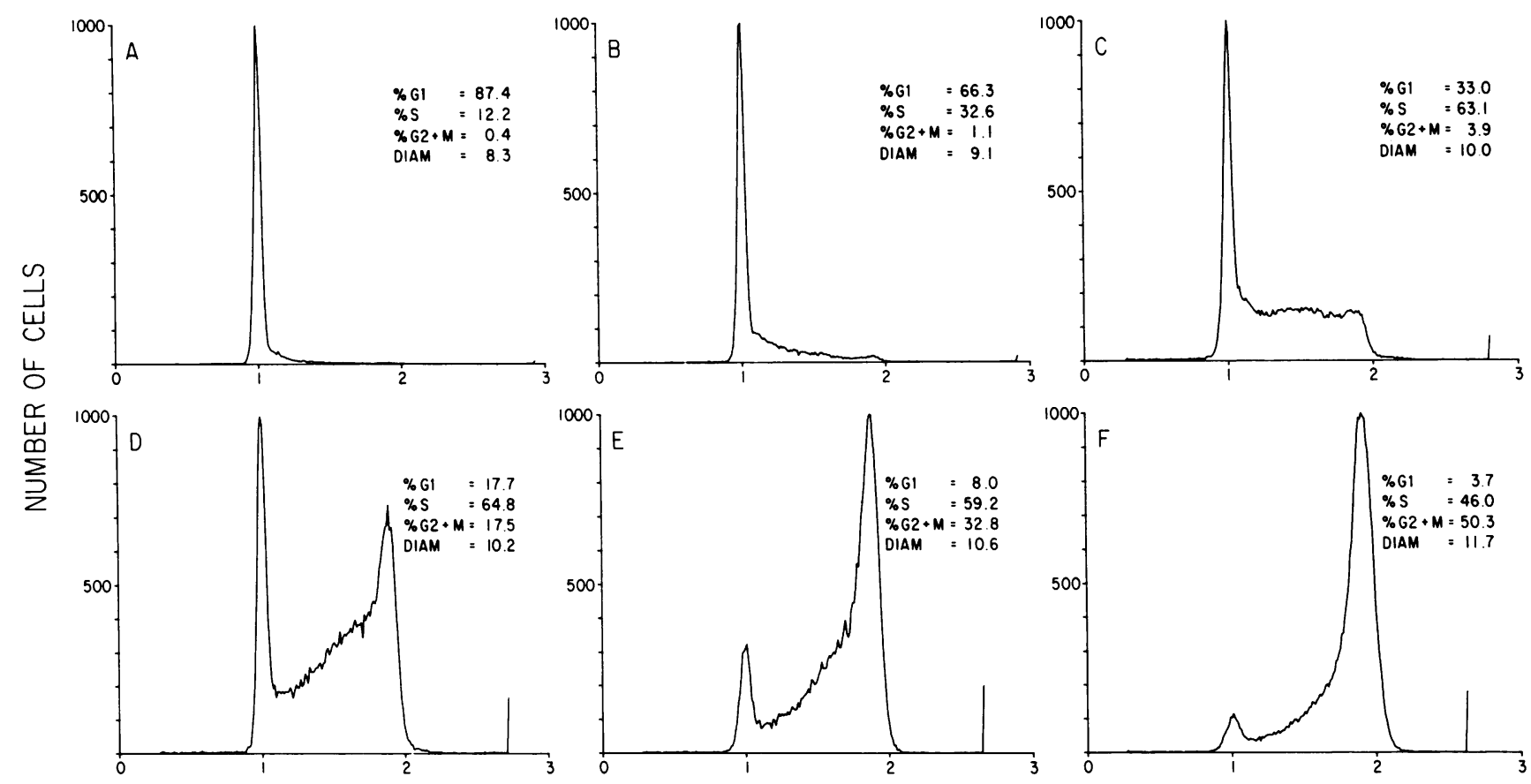

Figure 6. DNA histograms from NALM-1 cells separated by counterflow centrifugal elutriation. The percentage of cells in $G_{1}, S$, and $G_{2}$ $+\mathrm{M}$ phase, as well as their mean Coulter diameter, is shown for

each fraction. The cells show an increase in size from fractions $A-F$, with a corresponding progressive enrichment for cells in the $S$ and $G_{2}$ $+M$ phases of the cell cycle. diam, diameter.

rangement comprise blasts with marginally detectable as well as undetectable CALLA. Thus, a plausible hierarchy of CALLA expression would be one in which the antigen is initially absent

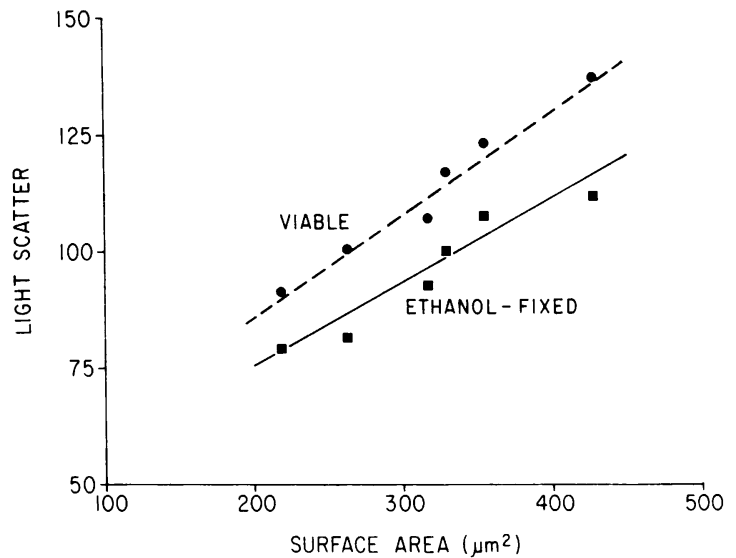

Figure 7. Mean cellular light scatter relative to the microsphere control (1.0) was determined before and after ethanol fixation, and is shown as a function of the mean calculated surface area $\left(\mu \mathrm{m}^{2}\right)$ based on the Coulter diameter for each fraction (assuming a spherical shape, $\pi \mathrm{D}^{2}$ ). The least-squares linear regression lines demonstrate a linear relationship between light scatter and surface area of both viable and ethanol-fixed cells ( $r=0.99$ and 0.96 , respectively).

or low (depending on the limits of detection) for HLA-DR ${ }^{+}$B cell precursors with only heavy chain rearrangement, increases to maximal levels as cells proceed to light chain gene rearrangement, and then decreases to undetectable levels on more mature, $\mathrm{SIg}^{+} \mathrm{B}$ cells. The molecular basis of differential CALLA expression on $B$ cell precursors and its possible relation to the sequence of $\mathrm{Ig}$ gene rearrangement remain unknown.

The 11 cases of $\mathrm{Clg}^{+}$pre-B ALL represent an interesting subgroup in this study. CALLA was undetectable in two cases and ranged from 1.3-17.6 relative units in the nine CALLA ${ }^{+}$ cases. These results indicate that amount of CALLA per cell does not depend on productive heavy chain gene rearrangement leading to $\mathrm{CIg}$ expression. The wide quantitative variation of CALLA expression in this subgroup is consistent with the proposed hierarchy of CALLA expression within the B cell precursor pathway, since an effectively rearranged $\mu$-chain gene could occur in cells blocked at any stage relative to light chain gene rearrangement.

In each of the 35 CALLA $^{+}$cases, the antigen was detected on $G_{0} / G_{1}$-phase as well as $S$ phase blasts, demonstrating that its presence does not depend on cell cycle phase. Nonetheless, we recorded appreciable increases of CALLA as blasts moved from $G_{0} / G_{1}$ into $S$. Unlike the kinetics of several other cell surface antigens, including HLA-DR (18-20), this change does not appear to be under independent cell cycle control, as the net increase of CALLA in S phase corresponded approximately to increased cell size (surface area). 

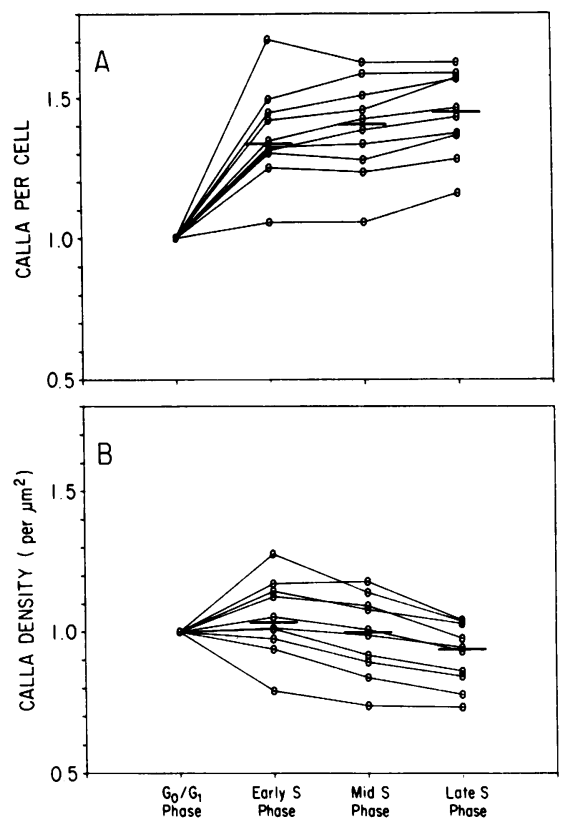

Figure 8. Analysis of mean CALLA expression for cells in early, mid, and late $S$ phase compared with $G_{0} / G_{1}$ phase for 10 patients with the highest percentage of $\mathrm{S}$ phase cells. In $A$, CALLA amount increased by a median of 1.33-fold in early $\mathrm{S}, 1.40$-fold in mid $\mathrm{S}$, and 1.45 -fold in late $S$ compared with $G_{0} / G_{1}$ phase (1.0). In $B$, CALLA density per unit of blast surface area $\left(\mu \mathrm{m}^{2}\right)$ is shown for the same intervals studied in $A$. In contrast to the preceding results, CALLA density remained relatively constant as cells progressed from $G_{0} / G_{1}$ - through $S$ phase. The mean surface area for each data point was calculated from the mean light scatter measurements using the correlation shown in Fig. 7.

The relatively low failure rate for patients with B cell precursor ALL makes identification of prognostic factors much more difficult than in comparisons between ALL subclasses characterized by strikingly different treatment responses (e.g., $B$ precursor vs. $T$ cell). Thus, any prognostic distinctions within the B precursor group are likely to be subtle and marginally significant, especially when small numbers of patients are analyzed. Despite this caveat, several investigators have noted an association between the presence of CALLA and a more favorable prognosis $(2,4,5)$. We extend this observation by demonstrating prognostic importance for quantitative level of the antigen. Although WBC also had prognostic value in our series, as in others (2-4), CALLA amount retained its influence after adjustment for this clinical variable. The combination of these two factors clearly had more predictive strength than either alone, suggesting that they might be used in concert to assign risk categories within the B cell precursor group.

How does relative amount of CALLA contribute to treatment outcome? We found no evidence to suggest a relationship with initial leukemic cell burden (as reflected by WBC), cell migration pattern (as reflected by spleen size), or cell proliferative capacity (as reflected by the percentage of cells in S phase). It may be that stages of cell differentiation within the B precursor series

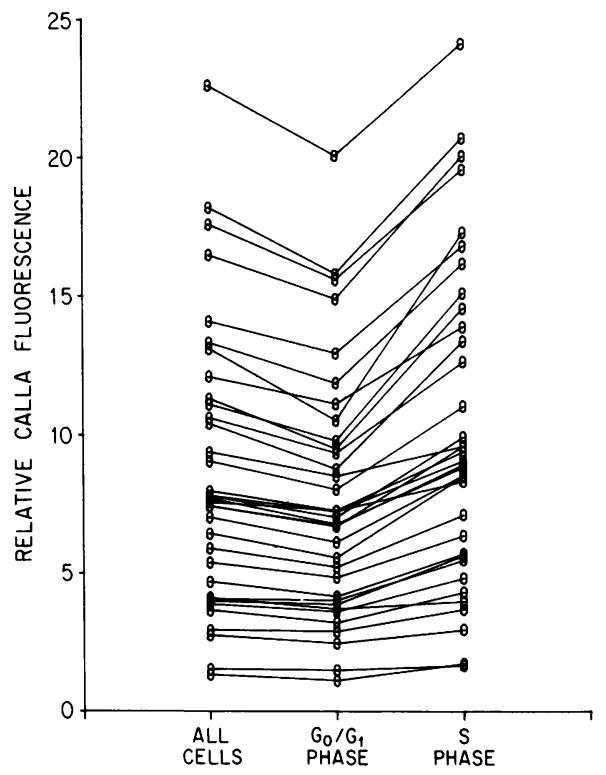

Figure 9. Mean cellular CALLA expression for bone marrow lymphoblasts from 35 patients with B cell precursor ALL. Measurements for the combined cell populations are shown in the first column. Comparison of the second and third columns shows uniformly higher mean values for $\mathrm{S}$ phase cells.

are linked to differences in cellular metabolism that affect drug sensitivity. Alternatively, CALLA itself, as a distinctive cell surface glycoprotein, might mediate reactions that influence drug sensitivity.

Although S phase blasts comprised only a small proportion of each patient's leukemic cell population, they are obviously important because they are actively committed to cell division

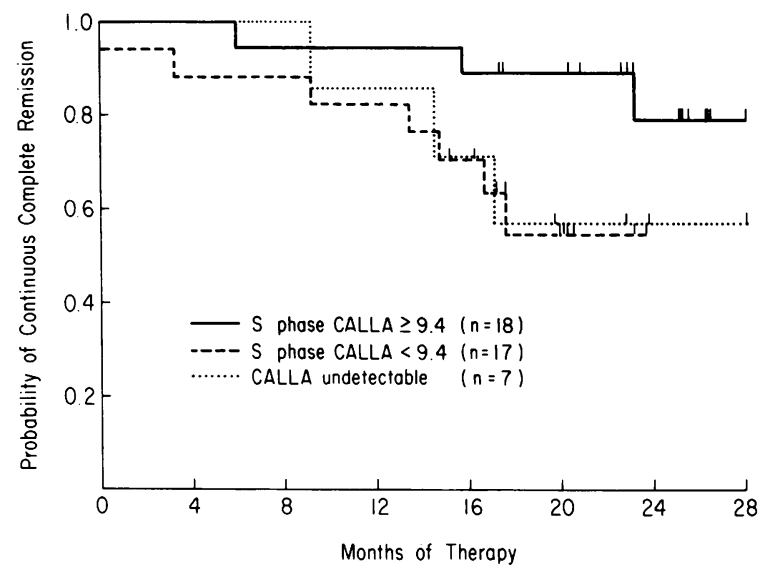

Figure 10. Time-to-failure curves for 42 patients with mean $\mathrm{S}$ phase CALLA expression $(a)$ equal to or greater than the median value, $(b)$ less than the median, or $(c)$ not detectable by our FCM methods. The difference between the $\geq 9.4$ and $<9.4$ groups is marginally significant $\left(\chi^{2}=3.59, P=0.058\right)$. 
Table III. Relationship of Selected Variables to Time to Failure

\begin{tabular}{|c|c|c|c|c|}
\hline \multirow[b]{2}{*}{ Variable } & \multicolumn{2}{|l|}{ Category } & \multirow{2}{*}{$\begin{array}{l}\text { P value from } \\
\text { the likelihood } \\
\text { ratio test* }\end{array}$} & \multirow{2}{*}{$\begin{array}{l}\text { Estimated ratio } \\
\text { of hazard } \\
\text { function } \neq\end{array}$} \\
\hline & A & B & & \\
\hline \multicolumn{5}{|l|}{ CALLA (relative units) } \\
\hline All cells & $<7.6(n=24)$ & $\geq 7.6(n=18)$ & 0.493 & 1.48 \\
\hline $\mathrm{G}_{0} \mathrm{G}_{1}$ phase cells & $<6.9(n=24)$ & $\geq 6.9(n=18)$ & 0.167 & 2.25 \\
\hline S phase cells & $<9.4(n=24)$ & $\geq 9.4(n=18)$ & 0.048 & 3.35 \\
\hline $\log _{10} W B C$ & Continuous variable & & 0.012 & 4.66 \\
\hline Age $(y r)$ & $2-10(n=29)$ & Other $(n=13)$ & 0.445 & 1.62 \\
\hline Sex & Boys $(n=27)$ & Girls $(n=15)$ & 0.104 & 3.03 \\
\hline Race & Black $(n=3)$ & White $(n=39)$ & 0.846 & 1.23 \\
\hline Ploidy & Diploid $(n=33)$ & Aneuploid $(n=9)$ & 0.424 & 1.79 \\
\hline Spleen size $(\mathrm{cm})$ & $\geq 5(n=8)$ & $\leq 4(n=34)$ & 0.774 & 1.21 \\
\hline Percentage of $S$ phase cells & $<6.4 \%(n=16)$ & $\geq 6.4(n=26)$ & 0.197 & 2.05 \\
\hline Risk of failure" & High $(n=3)$ & Standard $(n=39)$ & 0.189 & 3.25 \\
\hline \multicolumn{5}{|l|}{$S$ phase CALLA adjusted for } \\
\hline $\log _{10}$ WBC & - & - & 0.062 & 3.16 \\
\hline$S$ phase CALLA $+\log _{10} \mathrm{WBC}$ & - & - & 0.007 & $13.94 \S$ \\
\hline
\end{tabular}

* This analysis indicates whether the proportional hazards model including a given variable provides a better fit with treatment outcome than does a model without the variable. For the combination of $S$ phase CALLA and $\log _{10}$ WBC, we tested whether addition of S phase CALLA improved the fit over a univariate model including $\log _{10}$ WBC only ( $S$ phase CALLA adjusted for $\log _{10} \mathrm{WBC}$ ), as well as whether the pair of variables provides a better fit than a model with no variables. $¥$ For all variables except $\log _{10} \mathrm{WBC}$, this ratio represents the estimated proportionate increase in hazard of treatment failure at any given time for a patient in category A vs. one in category B. For example, the estimated hazard rate for a patient with $S$ phase CALLA $<9.4$ relative units is 3.35 times that for a patient with $S$ phase CALLA $\geq 9.4$. For the continuous variable $\log _{10} \mathrm{WBC}$, the ratio represents the proportionate increase in hazard due to a 10 -fold increase in WBC. $\S$ In this estimate, the hazard ratio refers to low S phase CALLA + high WBC vs. high S phase CALLA + low WBC. "See Table II for criteria used in risk assignment; high-risk and standard-risk designations are synonymous with treatment group, as described in Methods.

and are the cells most affected by many of the drugs used in leukemia therapy (37). The stronger association between prognosis and CALLA expression by $S$ phase cells, as compared to $\mathrm{G}_{0} / \mathrm{G}_{1}$ phase cells or the combined cell population, most likely

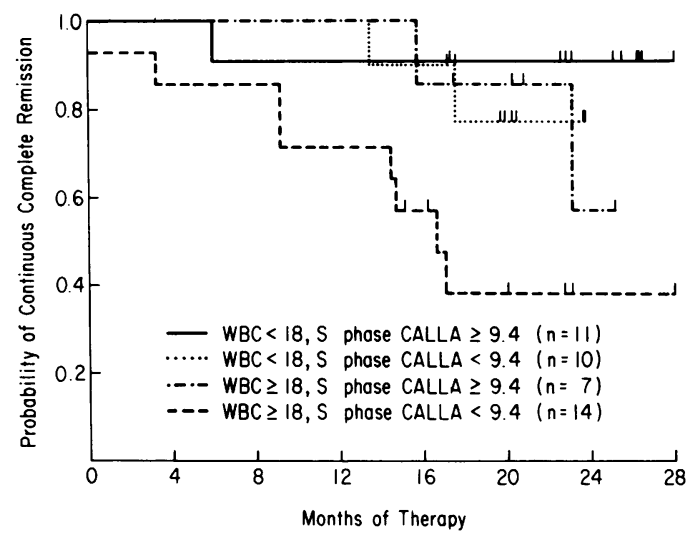

Figure 11. Time-to-failure curves derived from treatment responses of patients grouped by WBC $\left(\times 10^{9} /\right.$ liter $)$ and S phase CALLA above or below median values. Results for patients with the most favorable features (WBC $<18, S$ phase CALLA $\geq 9.4)$ differ significantly from those for the group with the least favorable features (WBC $\geq 18, S$ phase CALLA $<9.4)\left(\chi^{2}=5.85, P=0.016\right)$. reflects an increased uniformity of CALLA measurement within this well-defined region of the cell cycle. Flow cytometric analysis of DNA content does not distinguish $G_{0}$ and $G_{1}$ phase cells from each other. In view of the importance of $S$ phase cells in the growth and therapeutic response of leukemic cell populations, the characteristics of this subpopulation may furnish the most valuable information for predicting treatment outcome.

The versatility of FCM analysis has not been fully exploited in the measurement of antigens on leukemic cells. In any scheme of the sequential acquisition of surface antigens with differentiation, the influence of quantitative variation in the amount of antigen expressed and the lower limit of detection by the methods employed must be considered $(16,17)$. The flow cytometer is the ideal instrument with which to quantitate monoclonal antibody binding to specific surface markers expressed by leukemic cells in concert with other important cellular features. The next logical step is to use new multilaser FCM systems to assess the extent of differentiation within a leukemic cell population by simultaneously measuring the quantitative expression of multiple differentiation markers in addition to cell size and cell cycle phase $(38,39)$.

\section{Acknowledgments}

We thank Dr. Patrick Buckley for the Coulter diameter measurements, Dr. Donna Gandour for performing the centrifugal elutriations, Dr. 
Mary Anne Roper for performing some of the CIg analyses, Dr. William Walker for helpful discussions, Alvin J. Culp for writing computer programs used to plot the FCM data, John Gilbert for editorial review and critical comments, and the entire staff of the Leukemia-Lymphoma Service for assistance in procuring patient samples. We acknowledge the expert technical assistance of Barry Somerville, Ann Tipler, Susan Hilliard, Patricia A. Ball, Mary Anne Ouellette, and Jacqueline Burns.

This work was supported in part by Cancer Center Support (Core) grant CA-21765, Leukemia Program Project grant CA-20180, and by the American Lebanese Syrian Associated Charities (ALSAC).

\section{References}

1. Greaves, M. F., G. Brown, N. T. Rapson, and T. A. Lister. 1975. Antisera to acute lymphoblastic leukemia cells. Clin. Immunol. Immunopathol. 4:67-84.

2. Greaves, M. F., G. Janossy, J. Peto, and K. Humphrey. 1981. Immunologically defined subclasses of acute lymphoblastic leukemia in children: their relationship to presentation features and prognosis. $\mathrm{Br}$. J. Haematol. 48:179-197.

3. Bowman, W. P., S. L. Melvin, R. J. A. Aur, and A. M. Mauer. 1981. A clinical perspective of cell markers in acute lymphocytic leukemia. Cancer Res. 41:4704-4801.

4. Kersey, J., A. Goldman, C. Abramson, M. Nesbit, G. Perry, K. Gajl-Peczalska, and T. LeBien. 1982. Clinical usefulness of monoclonal antibody phenotyping in childhood acute lymphoblastic leukemia. Lancet II:1419-1423.

5. Sallan, S. E., J. Ritz, J. Pesando, R. Gelber, C. O’Brien, S. Hitchcock, F. Coral, and S. F. Schlossman. 1980. Cell surface antigens: prognostic implications in childhood acute lymphoblastic leukemia. Blood. 55:395-402.

6. Greaves, M., D. Delia, G. Janossy, N. Rapson, J. Chessels, M. Woods, and G. Prentice. 1980. Acute lymphoblastic leukaemia associated antigen. IV. Expression on non-leukemic 'lymphoid' cells. Leuk. Res. 4:15-32.

7. Janossy, G., F. J. Bollum, K. F. Bradstock, A. McMichael, N. Rapson, and M. F. Greaves. 1979. Terminal transferase-positive human bone marrow cells exhibit the antigenic phenotype of common acute lymphoblastic leukemia. J. Immunol. 123:1525-1529.

8. Janossy, G., F. J. Bollum, K. F. Bradstock, and J. Ashley. 1980. Cellular phenotypes of normal and leukemic hemopoietic cells determined by analysis with selected antibody combinations. Blood. 56:430441.

9. Greaves, M. F., G. Hariri, R. A. Newman, D. R. Sutherland, M. A. Ritter, and J. Ritz. 1983. Selective expression of the common acute lymphoblastic leukemia (gp100) antigen on immature lymphoid cells and their malignant counterparts. Blood. 61:628-639.

10. Sutherland, R., J. Smart, P. Niaudet, and M. Greaves. 1978. Acute lymphoblastic leukemia associated antigen. II. Isolation and partial characterization. Leuk. Res. 2:115-126.

11. Veit, B. C., S. L. Melvin, and W. P. Bowman. 1980. Identification of a leukemia-associated antigen of human acute lymphocytic leukemia. J. Natl. Cancer Inst. 64:1321-1328.

12. Newman, R. A., R. Sutherland, and M. F. Greaves. 1981. The biochemical characterization of a cell surface antigen associated with acute lymphoblastic leukemia and lymphocyte precursors. J. Immunol. 126:2024-2030.

13. Ritz, J., J. M. Pesando, J. N. Notis-McConarty, H. Lazarus, and S. F. Schlossman. 1980. A monoclonal antibody to human acute lymphoblastic leukaemia antigen. Nature (Lond.). 283:583-585.
14. LeBien, T. W., D. R. Boue, J. G. Bradley, and J. H. Kersey. 1982. Antibody affinity may influence antigenic modulation of the common acute lymphoblastic leukemia antigen in vitro. J. Immunol. 129:2287-2292.

15. Korsmeyer, S. J., A. Arnold, A. Babhshi, J. V. Ravetch, V. Siebenlist, P. A. Hieter, S. O. Sharrow, T. W. LeBien, J. H. Kersey, D. G. Poplack, P. Leder, and T. A. Waldmann. 1983. Immunoglobulin gene rearrangement and cell surface antigen expression in acute lymphocytic leukemias of T-cell and B-cell precursor origins. J. Clin. Invest. 71:301-313.

16. Warner, N. L., M. J. Daley, J. Richey, and C. Spellman. 1979. Flow cytometry analysis of murine B cell lymphoma differentiation. Immunol. Rev. 48:197-243.

17. Slease, R. B., R. Wistar, Jr., and I. Scher. 1979. Surface immunoglobulin density on human peripheral blood mononuclear cells. Blood. 54:72-87.

18. Sarkar, S., M. C. Glassy, S. Ferrone, and O. W. Jones. 1980. Cell cycle and the differential expression of HLA-A,B and HLA-DR antigens on human B lymphoid cells. Proc. Natl. Acad. Sci. USA. 77:7297-7301.

19. Lanier, L. L., and N. L. Warner. 1982. Cell cycle related heterogeneity of Ia antigen expression on a murine B lymphoma cell line: analysis by flow cytometry. J. Immunol. 126:626-631.

20. Burchiel, S. W., J. C. Martin, K. Imai, S. Ferrone, and N. L. Warner. 1982. Heterogeneity of HLA-A,B, Ia-like, and melanoma-associated antigen expression by human melanoma cell lines analyzed with monoclonal antibodies and flow cytometry. Cancer Res. 42:41104115.

21. Braylan, R. C., N. A. Benson, V. Nourse, and H. S. Kruth. 1982. Correlated analysis of cellular DNA, membrane antigens and light scatter of human lymphoid cells. Cytometry. 2:337-343.

22. Bowman, W. P., J. Ochs, C.-H. Pui, D. K. Kalwinsky, M. Abromowitch, R. J. A. Aur, and J. V. Simone. 1983. New directions of St. Jude Total-Therapy protocols: Study $\mathrm{X}$ for standard-risk childhood acute lymphoblastic leukemia. In Leukemia Research: Advances in Cell Biology and Treatment. S. B. Murphy and J. R. Gilbert, editors. Elsevier Science Publishing Co., New York. 203-212.

23. Rivera, G., G. V. Dahl, S. B. Murphy, W. P. Bowman, M. Abromowitch, J. Ochs, C.-H. Pui, D. K. Kalwinsky, T. L. Avery, S. L. George, and J. V. Simone. 1983. The epipodophyllotoxin VM-26 in treatment of high-risk acute lymphoblastic leukemia: rationale and early results. In Leukemia Research: Advances in Cell Biology and Treatment. S. B. Murphy and J. R. Gilbert, editors. Elsevier Science Publishing Co., New York. 213-220.

24. Minowada, J., T. Tsubota, M. F. Greaves, and T. R. Walters. 1977. A non-T, non-B human leukemia cell line (NALM-1): establishment of the cell line and presence of leukemia-associated antigens. $J$. Natl. Cancer Inst. 59:83-87.

25. Crissman, H. A., and J. A. Steinkamp. 1973. Rapid, simultaneous measurement of DNA, protein, and cell volume in single cells from large mammalian cell populations. J. Cell Biol. 59:766-771.

26. Loken, M. R., D. R. Parks, and L. A. Herzenberg. 1977. Twocolor immunofluorescence using a fluorescence-activated cell sorter. $J$. Histochem. Cytochem. 25:899-907.

27. Krishan, A. 1975. Rapid flow cytofluorometric analysis of mammalian cell cycle by propidium iodide staining. J. Cell Biol. 66:188193.

28. Look, A. T., S. L. Melvin, D. L. Williams, G. M. Brodeur, G. V. Dahl, D. K. Kalwinsky, S. B. Murphy, and A. M. Mauer. 1982. Aneuploidy and percentage of S-phase cells determined by flow cytometry 
correlate with cell phenotype in childhood acute leukemia. Blood. 60:959967.

29. Nadler, L. M., P. Stashenko, R. Hardy, J. M. Pesando, E. J. Yunis, and S. F. Schlossman. 1981. Monoclonal antibodies defining serologically distinct HLA-D/DR related Ia-like antigens in man. Hum. Immunol. 1:77-90.

30. Vogler, L. B., W. M. Crist, A. M. Sarrif, D. J. Pullen, A. A. Bartolucci, J. M. Falletta, B. Dowell, G. B. Humphrey, R. Blackstock, J. van Eys, R. S. Metzgar, and M. D. Cooper. 1981. An analysis of clinical and laboratory features of acute lymphocytic leukemias with emphasis on 35 children with pre-B leukemia. Blood. 58:135-150.

31. Gandour, D. M., and W. S. Walker. 1983. Macrophage cell cycling: influence on $\mathrm{Fc}$ receptors and antibody-dependent phagocytosis. J. Immunol. 130:1108-1112.

32. Ryan, T. A., B. L. Joiner, and B. F. Ryan. 1976. Minitab Student Handbook. Duxbury Press, North Scituate, MA.
33. Kaplan, E. L., and P. Meier. 1958. Nonparametric estimation from incomplete observations. J. Am. Stat. Assoc. 53:457-481.

34. Peto, R., and J. Peto. 1972. Asymptotically efficient rank invariant test procedures. J. Royal Stat. Soc. A. 135:185-206.

35. Cox, D. R. 1972. Regression models and life tables. J. Royal Stat. Soc. B. 34:187-220.

36. Melamed, M. R., P. F. Mullaney, and M. L. Mendelsohn. 1979. Flow Cytometry and Sorting. John Wiley \& Sons, New York. 105-124.

37. Mauer, A. M., and B. C. Lampkin. 1974. Studies of leukemia cell proliferation. I. Reviews in leukemia and lymphomas. In Advances in Acute Leukemia. F. J. Cleton, D. Crowther, and S. S. Malpas, editors. Elsevier/North Holland Publishing Co., Amsterdam. 69-94.

38. Hardy, R. R., K. Hayakawa, J. Haaijman, and L. A. Herzenberg. 1982. B-cell sub-populations identified by 2-color fluorescence analysis. Nature (Lond.). 297:589-591.

39. Shapiro, H. M. 1983. Multistation multiparameter flow cytometry: a critical review and rationale. Cytometry. 3:227-243. 